\title{
FRONTOTEMPORAL DEMENTIAS: UPDATE ON RECENT DEVELOPMENTS IN MOLECULAR GENETICS AND NEUROPATHOLOGY
}

\author{
Rajka M. LIŠČIĆ \\ Institute for Medical Research and Occupational Health, Zagreb, Croatia
}

\begin{abstract}
Frontotemporal dementias (FTD) are the second most common type of presenile dementias, considered to be clinically and pathologically different from Alzheimer's dementia (AD). FTD differs clinically from AD because memory loss is rarely an early symptom. Instead, FTD is usually denoted by behavioural and language difficulties, and may co-occur with motor neuron disease (MND). Frontotemporal lobar degeneration (FTLD) with ubiquitin-positive, tau-negative inclusions (FTLD-U) is the most common underlying pathology with and without MND. TAR DNA-binding protein 43 (TDP-43), encoded by the TARDBP gene, has been identified as the major pathological protein of FTLD-U with or without MND, demonstrating that abnormal TDP-43 alone is sufficient to cause neurodegeneration. FTLD is a genetically complex disorder. A proportion of cases of FTLD-U have various pathogenic mutations in the progranulin (GRN) gene. Other FTLD-U entities with TDP-43 proteinopathy include FTLD-U with valosin-containing protein (VCP) gene mutation and FTLD with MND linked to chromosome 9p. In contrast, chromosome 3-linked dementia, a FTLD-U with chromatic modifying protein 2B (CHMP2B) mutation, has TDP-43 negative inclusions. Thus, TDP-43 defines a novel class of neurodegenerative diseases called TDP-43 proteinopathies. These recent discoveries will contribute to an accurate diagnosis, and facilitate the development of diagnosis and therapy.
\end{abstract}

KEY WORDS: frontotemporal lobar degeneration, granulin, motor neuron disease, mutation, TARDBP, TDP-43 protein

Frontotemporal dementias (FTD) are a clinically, genetically, and neuropathologically heterogeneous group of diseases accounting for up to $20 \%$ of presenile dementia cases. FTD is a focal, non-Alzheimer form of dementia, clinically characterised as behavioural and/or language dysfunction, and may co-occur with motor neuron disease (MND) (1). Typically, the patient with FTD does not have an amnestic syndrome, at least in the early stage of the disease, which distinguishes FTD clinically from Alzheimer's disease (AD) $(2,3)$, but there are exceptions (4). However, the clinical diagnosis of FTD may only be considered after other potential causes of dementia (e.g. small and/or large vessel disease), systemic conditions (e.g., hypothyroidism, vitamin B deficiency), tumours, and substance abuse have been excluded. Frontotemporal lobar degeneration (FTLD) with ubiquitin-positive, tau-negative inclusions (FTLD-U or FTLD-MNDtype) is the most common underlying pathology in FTD with and without MND (5). TAR DNA-binding protein 43 (TDP-43), a nuclear protein implicated in exon skipping and transcription regulation $(6,7$, 8 ) was recently identified as the major pathological protein of sporadic and familial FTLD-U, with and without MND, as well as in sporadic amyotrophic lateral sclerosis (ALS), $(9,10)$, and rapidly confirmed by others $(11,12)$. Pathologic TDP-43 in these disorders is abnormally phosphorylated, ubiquitinated and cleaved to generate $\mathrm{C}$-terminal fragments, and is recovered only from pathologically affected CNS regions including hippocampus, neocortex, and spinal cord (10). Therefore, the presence of abnormal 
aggregates of phoshorylated and ubiquitinated TDP-43 defines a novel class of neurodegenerative diseases called TDP-43 proteinopathies that includes FTLD-U, FTLD, MND, and ALS. The increasing life expectancy will result in increased prevalence of neurodegenerative diseases. This review focuses on exciting findings providing a number of important advances in our understanding of the neuropathology, molecular genetics, and biochemistry of FTD, as one of neurodegenerative diseases that have occurred recently in this rapidly developing field of dementia research.

\section{NEUROPATHOLOGY OF FTLD}

FTLD comprises a neuropathologically heterogeneous group of neurodegenerative diseases which share the common feature of predominant degeneration of the frontal and temporal lobes
(13-15). FTLD can broadly be divided into two main classes, based on abnormal accumulation of hyperphosphorylated tau protein: those with taupositive and with tau-negative inclusions. Whereas, in the past, most attention focused on FTLD associated with tau-based pathology and microtubule-associated protein tau gene (MAPT) mutations (tauopathies), there has recently been greater attention paid to nontau or tau-negative FTLD (non-tauopathies) (14). FTLD-U accounts for $5 \%$ to $15 \%$ of all dementia disorders (16).

\section{GENETIC STUDIES}

FTLD is a genetically complex disorder, with multiple genetic factors contributing to the disease. A positive family history with an autosomal dominant pattern of inheritance and high penetrance is usually found in one quarter to one half of patients $(17,18)$.

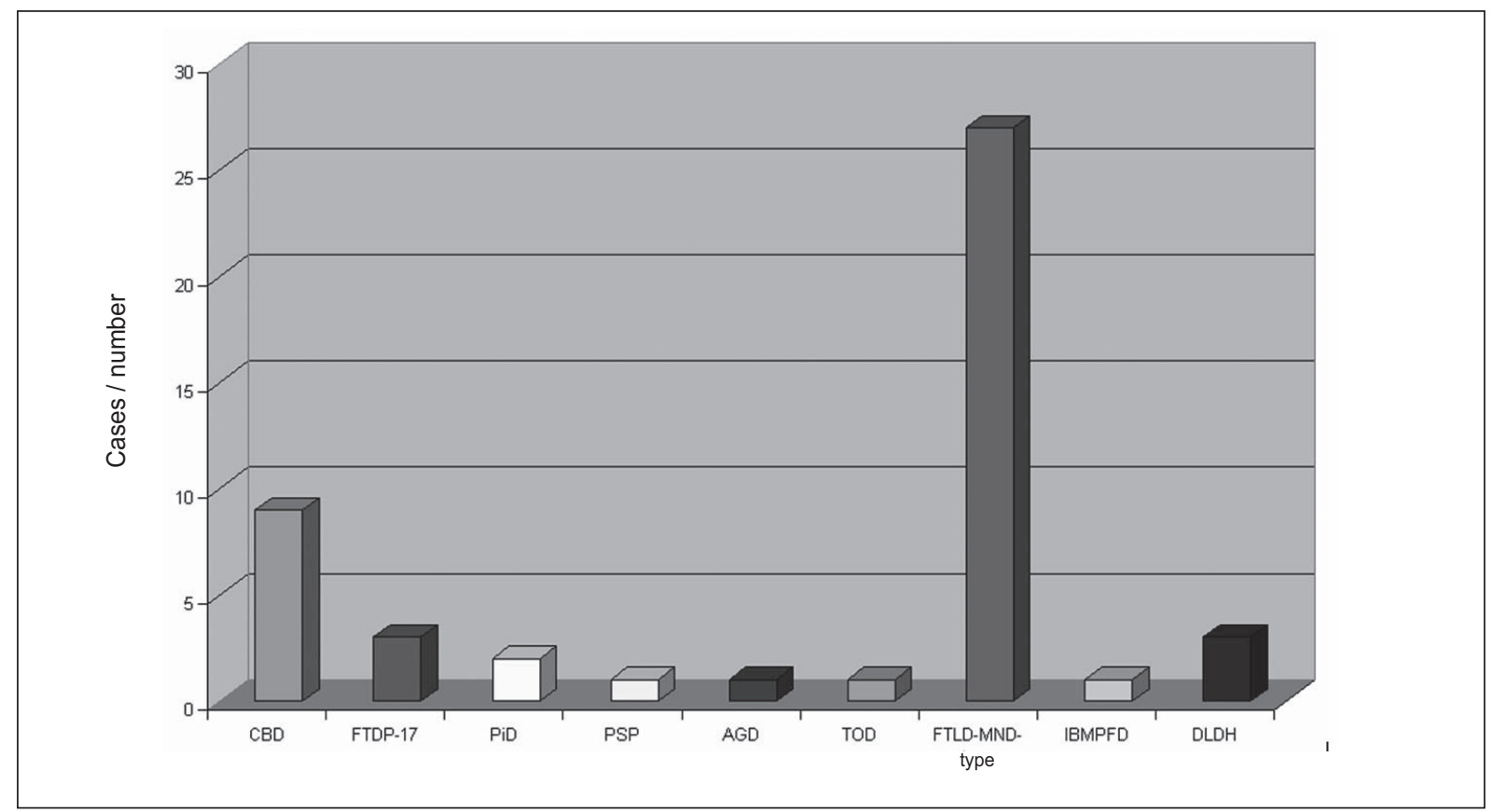

Figure 1 Spectrum of FTLD $(14,15)$ in a cohort of 48 cases published elsewhere (2). The FTLD-U (or FTLD-MND-type) is the most common pathology associated with clinical FTD

\section{Abbreviations:}

$C B D=$ corticobasal degeneration

FTDP17= frontotemporal dementia with parkinsonism linked to chromosome 17

PiD $=$ Pick's disease

$P S P=$ progressive supranuclear palsy

$A G D=$ argyrophilic grain disease

$T O D=$ tangle only dementia

FTLD-MND-type $=$ frontotemporal dementia with motor neuron disease type inclusions

$I B M P F D=$ inclusion body myopathy with Paget's disease of bone and frontotemporal dementia

$D L D H=$ dementia lacking distinctive histopathology 
Various pathogenic mutations in the progranulin $(G R N)$ gene were recently reported in individuals with FTLD-U linked to chromosome 17q21 $(19,20)$. The GRN gene is mutated in $5 \%$ to $10 \%$ of patients with FTD and in about $20 \%$ of patients with familial FTD (21), similar to that of FTD with MAPT mutations (22). For the current list of pathogenic mutations in FTLD please refer to: http://www.molgen.ua.ac. be/FTDMutations/. It is now recognised that FTLD$\mathrm{U}$ is the most common pathology associated with clinical FTLD (5). Also, several genes and a locus on chromosome 9 have been linked to familial FTLD-U. Genetic defects include mutations in the chromatin modifying protein $2 \mathrm{~B}$ (CHMP2B gene), the cause of chromosome 3-linked FTLD, and mutations in the valosin-contaning protein (VCP) gene associated with inclusion body myopathy, with Paget's disease, and with frontotemporal dementia, which is the cause of chromatin 9-linked FTLD $(18,23)$. Locus heterogeneity for FTLD and MND is indicated by the presence of other genetic loci at $9 p$. The ubiquitinated pathological protein in FTLD-U has been identified as TAR DNA-binding protein 43 (TDP-43) (9-11). As more entities are investigated, the pathological TDP43 protein is found to be a component of the inclusions of an increasing number of neurodegenerative diseases.

\section{CLINICAL PHENOTYPE OF FTD}

Recently, we retrospectively examined charts of 48 FTD individuals in order to find clinical differences between FTD and AD. All cases of FTD met pathological criteria for $\operatorname{FTLD}(14,15)$. Clinically, behavioural and language features, including impulsivity, disinhibition, and social withdrawal were significantly different between FTD and AD, as reported previously (24). The most distinctive feature of FTD, on psychometric tests, was a significant impairment of frontal lobe functioning, as reported earlier (25). The identification of different mutations in the GRN gene in hereditary dysphasic disinhibition dementia families 1 and 2 (HDDD 1 and HDDD 2) $(26,27)$ links these families to other FTLD-U families with $\operatorname{GRN}$ mutation $(28,29)$. A complicating feature in both HDDD families is the presence of AD-type early memory loss which correlated with coexisting AD pathology in almost half of the cases, which distinguishes them from other families with no or little coexisting neurodegenerative disease $(26,27)$.
Interestingly, another family with the same GRN A9D mutation has been reported in an individual with corticobasal syndrome (30), indicating, again, clinical heterogeneity associated with the same mutation.

\section{CONCLUSION}

For practicing clinicians, the knowledge that changes in behaviour and language difficulties distinguish those with FTD from AD is important, although clinical and cognitive features may overlap between the two. Typically, patients with FTD do not have an amnestic syndrome, at least in the early stage of the disease, which distinguishes them from AD.

Major discoveries have been made in the recent past in the genetics, biochemistry, and neuropathology of FTD. TDP-43, encoded by the TARDBP gene, is the major pathological protein of FTLD-U with or without MND. Thus, TDP-43 defines a novel class of neurodegenerative diseases called TDP-43 proteinopathies. FTLD-U is now recognised as the most common pathology associated with clinical FTLD. New developments such as the discovery of TDP-43 as disease protein have opened new view on FTD, as well as its relation to motor neuron disease.

In summary, the new genetic and pathological information now opens the way for a novel diagnostic approach. The diagnostic responsibility will increase with the development of new diagnostic tests. It is anticipated that these discoveries will contribute to an accurate diagnosis, and facilitate the development of specific therapy.

\section{Acknowledgements}

The author thanks Professor Nigel J Cairns, PhD, FRCPath, Director, Alzheimer's Disease Research Center Neuropathology Core, Washington University, St. Louis, MO, USA for his valuable comments of the manuscript. Dr. Liščić has been supported by a Fulbright grant (68428174) at the Alzheimer's Disease Research Center, Washington University School of Medicine, St. Louis, MO, USA.

This work was supported by the Ministry of Science, Education and Sports, Republic of Croatia (grant. no. 0221340036-2083 "Frontotemporal Dementia").

\section{RERENCES}

1. Neary D, Snowden JS, Mann DM. Classification and description of frontotemporal dementias. Ann NY Acad Sci 2000;920:46-51. 
2. Liscic RM, Storandt M, Cairns NJ, Morris JC. Clinical and psychometric distinction of frontotemporal and Alzheimer dementias. Arch Neurol 2007;64:535-40.

3. Liscic R. How to differentiate frontotemporal from Alzheimer's dementia? Recent developments in molecular genetics and neuropathology. Zdrav Vestn 2008;77:71-4.

4. Graham A, Davies R, Xuereb J, Halliday G, Kril J, Creasey H, Graham K, Hodges J. Pathologically proven frontotemporal dementia presenting with severe amnesia. Brain 2005;128:597-605.

5. Lipton AM, White CL III, Bigio EH. Frontotemporal lobar degeneration with motor neuron disease-type inclusions predominates in 76 cases of frontotemporal dementia. Acta Neuropathol 2004;108:379-85.

6. Burratti E, Dork T, Zuccato E, Pagani F, Romano M, Baalle FE. Nuclear factor TDP-43 and SR proteins promote in vitro and in vivo CFTR exon 9 skipping. EMBO J 2001;20:177484.

7. Burratti E, Brindisi A, Paganini F, Baralle FE. Nuclear factor TDP-43 binds to the polymorphic TG repeats in CFTR intron 8 and causes skipping of exon 9: a functional link with disease penetrance. Am J Hum Genet 2004;74:1322-5.

8. Mercado PA, Ayala YM, Romano M, Burrati E, Baralle FE. Depletion of TDP-43 pverrides the need for exonic and intronic splicing enhancers in the human apoA-II gene. Nucleic Acids Res 2005;33:6000-10.

9. Arai T, Hasegawa M, Akiyama H, Ikeda K, Nonaka T, Mori H, Mann D, Tsuchiya K, Yoshida M, Hashizume Y, Oda T. TDP-43 is a component of ubiquitin-positive taunegative inclusions in frontotemporal lobar degeneration and amyotrophic lateral sclerosis. Biochem Biophys Res Commun 2006;351:602-11.

10. Neumann M, Sampathu DM, Kwong LK, Truax AC, Micsenyi MC, Chou TT, Bruce J, Schuck T, Grossman M, Clark CM, McCluskey LF, Miller BL, Masliah E, Mackenzie IR, Feldman H, Feiden W, Kretzschmar HA, Trojanowski JQ, Lee VM. Ubiquitinated TDP-43 in frontotemporal lobar degeneration and amyotrophic lateral sclerosis. Science 2006;314:130-3.

11. Davidson Y, Kelley T, Mackenzie IR, Pickering-Brown S, Du Plessis D, Neary D, Snowdon JS, Mann DM. Ubiquitinated pathological lesions in frontotemporal lobar degeneration contains the TAR DNA-binding protein, TDP-43. Acta Neuropathol 2007;113:521-33.

12. Neumann M, Mackenzie IR, Cairns NJ, Boyer PJ, Markesbery WR, Smith CD, Paul Taylor J, Kretzschmar HA, Kimonis V, Forman MS. TDP-43 in the ubiquitin pathology of frontotemporal dementia with VCP mutations. J Neuropathol Exp Neurol 2007;66:152-7.

13. The Lund and Manchester Groups. Clinical and neuropathological criteria for frontotemporal dementia. J Neurol Neurosurg Psych 1994;57:416-8.

14. McKhann GM, Albert MS, Grossman M, Miller B, Dickson D, Trojanowski JQ. Clinical and pathological diagnosis of frontotemporal dementia: Report of the work Group on Frontotemporal Dementia and Pick's Disease. Arch Neurol 2001;58:1803-9.

15. Cairns NJ, Bigio EH, Mackenzie IR, Neumann M, Lee VMY, Hatanpaa K, White CL 3rd, Schneider JA, Grinberg LT, Halliday G, Duyckaerts C, Lowe JS, Holm IE, Tolnay M, Okamoto K, Yokoo H, Murayama S, Woulfe J, Munoz DG, Dickson DW, Ince PG, Trojanowski JQ, Mann DM;
Consortium for Frontotemporal Lobar Degeneration. Neuropathologic diagnostic and nosologic criteria for frontotemporal lobar degeneration: consensus of the Consortium for Frontotemporal Lobar Degeneration: Acta Neuropathol 2007;114:5-22.

16. Ikeda M, Ishikawa T, Tanabe H. Epidemiology of frontotemporal lobar degeneration. Dement Geriatr Cogn Disord 2004;17:265-8.

17. Bird T, Knopman D, van Swieten J, Rosso S, Feldman H, Tanabe H, Graff-Raford N, Geschwind D, Verpillat P, Hutton M. Epidemiology and genetics of frontotemporal dementia/ Pick's disease. Ann Neurol 2003;54(Suppl. 5):S29-31.

18. Liscic RM, Grinberg LT, Zidar J, Gitcho MA, Cairns NJ. ALS and FTLD: two faces of TDP-43 proteinopathy. Eur J Neurol 2008;15:772-80.

19. Baker M, Mackenzie IR, Pickering-Brown SM, Gass J, Rademakers R, Lindholm C, Snowden J, Adamson J, Sadovnick AD, Rollinson S, Cannon A, Dwosh E, Neary D, Melquist S, Richardson A, Dickson D, Berger Z, Eriksen J, Robinson T, Zehr C, Dickey CA, Crook R, McGowan E, Mann D, Boeve B, Feldman H, Hutton M. Mutations in progranulin cause tau-negative frontotemporal dementia linked to chromosome 17. Nature 2006;442:916-9.

20. Cruts M, Gijselinck I, van der Zee J, Engelborghs S, Wils H, Pirici D, Rademakers R, Vandenberghe R, Dermaut B, Martin JJ, van Duijn C, Peeters K, Sciot R, Santens P, De Pooter T, Mattheijssens M, Van den Broeck M, Cuijt I, Vennekens K, De Deyn PP, Kumar-Singh S, Van Broeckhoven C. Null mutations in progranulin cause ubiquitin-positive frontotemporal dementia linked to chromosome $17 \mathrm{q} 21$. Nature 2006;442:920-4.

21. Josephs KA, Holton JL, Rossor MN, Godbolt AK, Ozawa T, Strand K. Frontotemporal lobar degeneration and ubiquitin immunohistochemistry. Neuropathol App Neurobiol 2004;369-73.

22. Rademakers R, Cruts M, van Broeckhoven C. Epidemiology of frontotemporal dementia and related tauopathies. Human Mutation 2004;24:277-95.

23. Watts GD, Wymer J, Kovach MJ, Mehta SG, Mumm S, Darvish D, Pestronk A, Whyte MP, Kimonis VE. Inclusion body myopathy associated with Paget disease of bone and frontotemporal dementia is caused by mutant valosincontaining protein. Nature Genetics 2004;36:377-81.

24. Rosen HJ, Hartikainen KM, Jagust W, Kramer JH, Reed BR, Cummings JL. Utility of clinical criteria in differentiating frontotemporal lobar degeneration (FTLD) from AD. Neurology 2002;58:1608-15.

25. Rascovsky K, Salmon DP, Ho GJ, Galasko D, Peavy GM, Hansen LA. Cognitive profiles differ in autopsy-confirmed frontotemporal dementia and AD. Neurology 2002;58:18018.

26. Behrens MI, Mukherjee O, Tu PH, Liscic RM, Carter D, Taylor-Reinwald L, Norton J, Chakraverty S, Goate A, Morris JC, Cairns. Neuropathologic heterogeneity in HDDD1: a familial frontotemporal lobar degeneration with ubiquitin-positive inclusions and progranulin mutation. Alzheimer Dis Assoc Disord 2007;21:1-7.

27. Mukherjee O, Pastor P, Cairns NJ, Chakraverty S, Kauwe JSK, Shears S, Behrens MI, Budde J, Hinrichs AL, Norton J, Levitch D, Taylor-Reinwald L, Gitcho M, Tu P-H, Tenenholz Grinberg L, Liscic RM, Armendariz J, Morris JC, Goate AM. HDDD2 is a familial frontotemporal lobar degeneration 
with ubiquitin-positive, tau-negative inclusions caused by a missence mutation in the signal peptide of progranulin. Ann Neurol 2006;60:314-22.

28. Morris JC, Cole M, Banker BQ, Wright D. Hereditary dysphasic dementia and the Pick-Alzheimer spectrum. Ann Neurol 1984;16:455-66.
29. Lendon CL, Lynch T, Norton J, Goate A. Hereditary dysphasic disinhibition dementia: a frontotemporal dementia linked to 17q21-22. Neurology 1998;50:1546-55.

30. Spina S, Murrell J, Huey E. Corticobasal syndrome associated with the A9D progranulin mutation. J Neuropathol Exp Neurol 2007;66:892-900. 
Sažetak

\section{FRONTOTEMPORALNE DEMENCIJE - PRIKAZ NOVIH DOSTIGNUĆA IZ PODRUČJA MOLEKULARNE GENETIKE I NEUROPATOLOGIJE}

Frontotemporalne demencije (FTD) druga su po učestalosti grupa presenilnih demencija, koja se kliničkim simptomima i patologijom razlikuje od Alzheimerove demencije (AD). FTD se razlikuje od AD budući da je gubitak memorije rijetko prvi simptom bolesti. Umjesto toga, FTD karakteriziraju smetnje u ponašanju i govoru, a mogu se javiti i simptomi bolesti motornog neurona (BMN). Frontotemporalna lobarna degeneracija (FTLD) s ubikvitin-pozitivnim, tau-negativnim inkluzijama (FTLD-U) najučestalija je patološka slika s BMN-om ili bez njega. Glavni patološki protein FTLD-U s BMN-om ili bez njega je protein 43 vezan s DNA (TDP-43), kodiran od gena TARDBP, čija prisutnost je već dovoljna za nastanak neurodegenerativnih promjena. Glede genetike, FTLD je kompleksna bolest. Dio bolesnika s patološkom slikom FTLD-U pokazuje različite patološke mutacije progranulin (GRN) gena. Ostali FTLD-U entiteti s TDP-43-proteinopatijama uključuju: FTLD-U proteinom vezanim s valozinom i FTLD s BMN-om vezanim uz kromosom 9p. Nasuprot tomu, demencija vezana na kromosom 3, FTLD-U s CHMP2B-mutacijom, sadržava TDP-43-negativne inkluzije. Stoga, TDP-43-protein definira novu grupu neurodegenerativnih bolesti koje nazivamo TDP-43-proteinopatije. Ova novija otkrića pridonijet će točnijoj dijagnozi i ubrzati razvoj dijagnostike i terapije.

KLJUČNE RIJEČI: bolest motornog neurona, frontotemporalna lobarna degeneracija, granulin (GRN) mutacije, TARDBP, TDP-43 protein

\section{CORRESPONDING AUTHOR:}

Rajka Liščić, M.D., Ph.D.

Institute for Medical Research and Occupational Health

P. O. Box 291, HR-10001 Zagreb, Croatia

E-mail: rliscic@imi.hr 